\title{
Geochemical Multi-element ICP-OES Analysis of Borehole Waters from SE Anatolia
}

\author{
M. Zahir Duz ${ }^{\mathrm{a}}$, Mehmet Sagirdag ${ }^{\mathrm{b} *}$, Kadir Serdar Çelike, Mahmood A. Hasand, and Ersin Kilinç \\ ${ }^{a}$ Dicle University, Science Faculty, Chemistry Department, TR-21280 Diyarbakir, Turkey \\ ${ }^{b}$ Drinking Water Facility Metropolitan Municipality of Diyarbakir, Turkey \\ ${ }^{\mathrm{c}}$ Faculty of Art and Science, Department of Chemistry, Batman University, Batman, Turkey \\ d Department of Chemistry, Science Faculty, University of Duhok, Kurdistan, Irak \\ ${ }^{e}$ Mardin Artuklu University, Medical Laboratory Techniques, \\ Vocational Higher School of Healthcare Studies, 47200 Mardin, Turkey
}

\section{INTRODUCTION}

Water is an indispensable component for life. The human race in this 21 st century is faced with unprecedented challenges imposed by water scarcity, pollution, and water quality deterioration. Rapid industrialization and population growth in the last few decades have caused an increase in the demand for borehole water as well as a significant impairment in water quality throughout the world $(1,2)$. Groundwater and surface sources are known to contain various elements, some of which have been implicated to impair human health and cause disease (3). A variety of elements is commonly present in virtually all drinkable water which includes $\mathrm{Al}, \mathrm{As}, \mathrm{B}, \mathrm{Be}, \mathrm{Ca}, \mathrm{Cd}, \mathrm{Co}$, $\mathrm{Cr}, \mathrm{Fe}, \mathrm{Hg}, \mathrm{K}, \mathrm{Mg}, \mathrm{Mn}, \mathrm{Mo}, \mathrm{Na}, \mathrm{Ni}$, $\mathrm{Pb}, \mathrm{Se}, \mathrm{Sn}$, and $\mathrm{Zn}$. They are generally found in small quantities and play an important role in the body's metabolism (4-7). On the other hand, the World Health Organization (WHO) reported that high dietary intake of selenium (Se) per day of 6-21 $\mu \mathrm{g}$ for infants and children, 26 and $30 \mu \mathrm{g}$ for adolescent females and males, respectively, and 26 and $35 \mu \mathrm{g}$ for adult females and males, respectively, has been identified to cause gastrointestinal disturbances, discoloration of the skin, loss of hair, nail changes, and tooth decay. The negative effects of lead $(\mathrm{Pb})$ on health were already known to ancient civilizations.

\footnotetext{
*Corresponding authors.

E-mail: zabird@dicle.edu.tr (M.Z.Duz)

Tel.:+90412248 8001 (Ext. 3222)

E-mail: kilincersin@gmail.com (E. Kilinç)

Tel.:+ 90 (482) 2126949 (Ext. 7284)
}

\section{ABSTRACT}

Water supply from boreholes is today used by people from rural areas of Turkey more commonly due to the reduction of available surface water. For this reason, the concentrations of $\mathrm{Al}$, As, B, Be, Ca, Cd, Co, Cr, Fe, Hg, $\mathrm{K}, \mathrm{Mg}, \mathrm{Mn}, \mathrm{Mo}, \mathrm{Na}, \mathrm{Ni}, \mathrm{Pb}, \mathrm{Se}$, $\mathrm{Sn}$, and $\mathrm{Zn}$ in borehole waters of the Diyarbakır province (SE Anatolia) were determined in this study. Thirty borehole waters were sampled from different towns and villages. The samples were analyzed by inductively coupled plasma optical emission spectrometry (ICP-OES). The results of the analyses were compared with guidelines as set by Turkey, the WHO, and the EU. From the results it could be concluded that the ICP-OES method can be considered useful for the routine determination of trace elements in waters and similar matrices. For quality control purposes, the certified reference material TMDW-B Drinking Water was employed for validation. The recovery values were in the range of $93-101 \%$. The $\mathrm{Al}$, As, $\mathrm{B}, \mathrm{Be}, \mathrm{Cd}, \mathrm{Co}, \mathrm{Cr}, \mathrm{Hg}, \mathrm{Mn}, \mathrm{Mo}$, $\mathrm{Ni}, \mathrm{Pb}$, and $\mathrm{Sn}$ concentrations in the samples were found lower than the recommended LOD. The concentrations found were in the range of 12.71-111.4 $\mathrm{mg} / \mathrm{L}$ for $\mathrm{Na}, 0.76-3.07 \mathrm{mg} / \mathrm{L}$ for $\mathrm{K}, 9.62-115.5 \mathrm{mg} / \mathrm{L}$ for $\mathrm{Ca}$, $2.69-41.85 \mathrm{mg} / \mathrm{L}$ for $\mathrm{Mg},<\mathrm{LOD}$ of $0.12 \mathrm{mg} / \mathrm{L}$ for Se, <LOD of $0.21 \mathrm{mg} / \mathrm{L}$ for $\mathrm{Fe}$, and <LOD of $0.52 \mathrm{mg} / \mathrm{L}$ for $\mathrm{Zn}$. While some of the results were at acceptable guideline limits, the Se amount in six samples was higher than the suggested limit of $>10 \mu \mathrm{g} / \mathrm{L}$.
In 2013, WHO estimated that lead poisoning resulted in 143,000 deaths, and causes 600,000 new cases of children born with intellectual disabilities each year $(8,9)$.

The main sources of $\mathrm{Pb}$ contamination for humans are food and water. Children are more susceptible to the effects of $\mathrm{Pb}$ because they absorb $\mathrm{Pb}$ more readily than adults. $\mathrm{Pb}$ from environmental pollution is not carcinogenic, but even a low $\mathrm{Pb}$ exposure has detrimental and long-lasting effects on the renal, hemopoietic, and nervous systems $(10,11)$.

Copper $(\mathrm{Cu})$ is a naturally occurring element found in rocks, soil, water, plants, and animals. It is an essential element required for the growth of both plants, animals, and humans (12). But an excess of $\mathrm{Cu}$ can produce toxicological effects, including vasodilation, flushing, and cardiomyopathy (13).

Zinc ( $\mathrm{Zn})$, one of the most essential multi-elements, is a co-factor for more than 200 enzymes, and a deficiency causes nutritional problems. However, an excess of this metal can cause disturbances in the energy metabolism or an increase in oxidative stress, growth retardation, altered immune response, disturbed pregnancy, weight loss, and anorexia, among others (14).

Some groundwater, surface water, and well water contains the arsenic (As) species of arsenate $\left(\mathrm{As}^{5+}\right)$ and arsenite $\left(\mathrm{As}^{3+}\right)$, which have become one of the most serious problems $(15,16)$.

Some essential trace elements in water are V, Cr, $\mathrm{Mn}, \mathrm{Fe}, \mathrm{Co}, \mathrm{Cu}, \mathrm{Zn}$, 
Se, Sr, K, Ca, Mg, and Mo $(17,18)$. Recent environmental studies have been devoted to analyzing trace elements in order to establish the concentration of organic and inorganic pollutants and their chemical composition to protect the health of the population (19-23). Table I provides a comparison of the daily maximum allowable concentrations (MAC) of elements as regulated by WHO, the European Union (EU), the United States, Canada, Turkey, and the P.R. of China. Table II lists the daily intake of elements per day through food, water, and air, toxic quantities, mean levels in the body, and half-life of the elements (24-27).

Water scarcity in some countries, such as Turkey, has become a critical issue in recent years, while the concern that fresh water will become a scarcer source in the future has been reported $(28,39)$. The use of borehole water is increasing in many communities of the world due to the reduction of surface water arising from the unobvious use and pollution from anthropogenic activities, etc. In this study, the analysis of borehole waters from 30 different towns and some rural areas of the Diyarbakir province (South East Anatolia of Turkey) have been investigated. The main aim of this study was to check whether the trace element levels comply with international standards for borehole waters from 30 different points of Diyarbakir.

\section{EXPERIMENTAL}

\section{Instrumentation}

A PerkinElmer ${ }^{\circledR}$ Optima ${ }^{\mathrm{TM}} 2100$ DV inductively coupled plasma optical emission spectrometer (ICPOES) (PerkinElmer, Shelton, CT, USA) was used for the determination of $\mathrm{Al}, \mathrm{As}, \mathrm{B}, \mathrm{Be}, \mathrm{Ca}, \mathrm{Cd}, \mathrm{Co}, \mathrm{Cr}$, $\mathrm{Fe}, \mathrm{Hg}, \mathrm{K}, \mathrm{Mg}, \mathrm{Mn}, \mathrm{Mo}, \mathrm{Na}, \mathrm{Ni}, \mathrm{Pb}$, $\mathrm{Se}, \mathrm{Sn}$, and $\mathrm{Zn}$ in water samples by considering the related references $(30,31)$. Table III lists the instrumental operating conditions and

TABLE I

Maximum Allowable Concentration for Trace Elements in Drinking Water as Regulated by the Various Countries (24-27)

\begin{tabular}{|c|c|c|c|c|c|c|}
\hline Elemen & nt WHO & E.U. & U.S. & China & Canada & Turkey \\
\hline As & $10 \mu \mathrm{g} / \mathrm{L}$ & $10 \mu \mathrm{g} / \mathrm{L}$ & $10 \mu \mathrm{g} / \mathrm{L}$ & $50 \mu \mathrm{g} / \mathrm{L}$ & $10 \mu \mathrm{g} / \mathrm{L}$ & $10 \mu \mathrm{g} / \mathrm{L}$ \\
\hline $\mathrm{Sb}$ & NS & $5.0 \mu \mathrm{g} / \mathrm{L}$ & $6.0 \mu \mathrm{g} / \mathrm{L}$ & NS & $6.0 \mu \mathrm{g} / \mathrm{L}$ & NS \\
\hline $\mathrm{Ba}$ & $700 \mu \mathrm{g} / \mathrm{L}$ & NS & $2.0 \mathrm{mg} / \mathrm{L}$ & NS & $1.0 \mathrm{mg} / \mathrm{L}$ & NS \\
\hline B & $2.4 \mathrm{mg} / \mathrm{L}$ & $1.0 \mathrm{mg} / \mathrm{L}$ & NS & NS & $5.0 \mathrm{mg} / \mathrm{L}$ & $1.0 \mu \mathrm{g} / \mathrm{L}$ \\
\hline $\mathrm{Cd}$ & $3.0 \mu \mathrm{g} / \mathrm{L}$ & $5.0 \mu \mathrm{g} / \mathrm{L}$ & $5.0 \mu \mathrm{g} / \mathrm{L}$ & $5 \mu \mathrm{g} / \mathrm{L}$ & $5.0 \mu \mathrm{g} / \mathrm{L}$ & $5.0 \mu \mathrm{g} / \mathrm{L}$ \\
\hline $\mathrm{Cr}^{6+}$ & $50 \mu \mathrm{g} / \mathrm{L}$ & $50 \mu \mathrm{g} / \mathrm{L}$ & $0.1 \mathrm{mg} / \mathrm{L}$ & $50 \mu \mathrm{g} / \mathrm{L}$ & $0.05 \mathrm{mg} / \mathrm{L}$ & $50 \mu \mathrm{g} / \mathrm{L}$ \\
\hline $\mathrm{Cu}$ & $2.0 \mathrm{mg} / \mathrm{L}$ & $2.0 \mathrm{mg} / \mathrm{L}$ & NS & $1.0 \mathrm{mg} / \mathrm{L}$ & $1.0 \mathrm{mg} / \mathrm{L}$ & $2.0 \mathrm{mg} / \mathrm{L}$ \\
\hline $\mathrm{Pb}$ & $10 \mu \mathrm{g} / \mathrm{L}$ & $10 \mu \mathrm{g} / \mathrm{L}$ & $15 \mu \mathrm{g} / \mathrm{L}$ & $10 \mu \mathrm{g} / \mathrm{L}$ & $10 \mu \mathrm{g} / \mathrm{L}$ & $10 \mu \mathrm{g} / \mathrm{L}$ \\
\hline $\mathrm{Hg}$ & $6.0 \mu \mathrm{g} / \mathrm{L}$ & $1.0 \mu \mathrm{g} / \mathrm{L}$ & $2.0 \mu \mathrm{g} / \mathrm{L}$ & $0.05 \mu \mathrm{g} / \mathrm{L}$ & $1.0 \mu \mathrm{g} / \mathrm{L}$ & $1.0 \mu \mathrm{g} / \mathrm{L}$ \\
\hline $\mathrm{Ni}$ & $20 \mu \mathrm{g} / \mathrm{L}$ & $20 \mu \mathrm{g} / \mathrm{L}$ & $20 \mu \mathrm{g} / \mathrm{L}$ & NS & NS & $20 \mu \mathrm{g} / \mathrm{L}$ \\
\hline $\mathrm{Se}$ & $40 \mu \mathrm{g} / \mathrm{L}$ & $10 \mu \mathrm{g} / \mathrm{L}$ & $50 \mu \mathrm{g} / \mathrm{L}$ & $10 \mu \mathrm{g} / \mathrm{L}$ & $10 \mu \mathrm{g} / \mathrm{L}$ & $10 \mu \mathrm{g} / \mathrm{L}$ \\
\hline $\mathrm{Ca}$ & NS & NS & NS & NS & $200 \mathrm{mg} / \mathrm{L}$ & NS \\
\hline $\mathrm{Mg}$ & NS & NS & NS & NS & $50 \mathrm{mg} / \mathrm{L}$ & NS \\
\hline $\mathrm{Zn}$ & NS & NS & NS & NS & $5.0 \mathrm{mg} / \mathrm{L}$ & $5.0 \mathrm{mg} / \mathrm{L}$ \\
\hline $\mathrm{Fe}$ & NS & $200 \mu \mathrm{g} / \mathrm{L}$ & NS & NS & $0.30 \mathrm{mg} / \mathrm{L}$ & $200 \mu \mathrm{g} / \mathrm{L}$ \\
\hline $\mathrm{Mn}$ & NS & $200 \mu \mathrm{g} / \mathrm{L}$ & NS & NS & $0.05 \mathrm{mg} / \mathrm{L}$ & $50 \mu \mathrm{g} / \mathrm{L}$ \\
\hline $\mathrm{Ag}$ & NS & NS & NS & NS & $0.05 \mathrm{mg} / \mathrm{L}$ & NS \\
\hline $\mathrm{U}$ & $30 \mu \mathrm{g} / \mathrm{L}$ & NS & NS & NS & $0.10 \mathrm{mg} / \mathrm{L}$ & NS \\
\hline $\mathrm{Na}$ & $200 \mathrm{mg} / \mathrm{L}$ & $200 \mathrm{mg} / \mathrm{L}$ & NS & NS & $200 \mathrm{mg} / \mathrm{L}$ & $200 \mu \mathrm{g} / \mathrm{L}$ \\
\hline $\mathrm{Al}$ & NS & $200 \mathrm{mg} / \mathrm{L}$ & NS & NS & NS & NS \\
\hline
\end{tabular}

NS : Not specified, indicates that no standard exists.

the most sensitive analytical lines of the analytes without spectral interference in the sample matrix. The concentrations of As, Se, and $\mathrm{Hg}$ were measured by using a continuous-flow hydride generation apparatus (Chemifold+Gas/Liquid Separator Manifold, PerkinElmer, Shelton, CT, USA). The experimental parameters are listed in Table III.

\section{Sampling}

The borehole waters sampled were in the Diyarbakir province $\left(37^{\circ} 55^{\prime} \mathrm{N}, 40^{\circ} 14^{\prime} \mathrm{E}\right)$, located at the North Mesopotamia and Southeastern Anatolia regions of Turkey. The total area of Diyarbakir encompasses $15,355 \mathrm{~km}^{2}$, of which about 2000 $\mathrm{km}^{2}$ are classified as urban. The continental climate is subtropical $(28,29)$. The area is a basin surrounded by mountains, one of which is Karacadag (black mountain), an extinct volcanic mountain. The population of the Diyarbakir area (urban and rural) in 1997 was $1,282,678$ and in 2014 reached $1,607,437$. In this area, 30 sampling stations were established with the main purpose of identifying critical situations of water quality degradation as a result of urban pollution (32).

Water samples were collected according to the standard method (30). Details about the sampling points for the 30 borehole samples are listed in Table IV. The samples were taken from the tank containing the borehole water used both for drinking and irrigation purposes by the local inhabitants. In order to prevent any possible contamination from metal cations, the water sam- 


\section{Atomic Apectroscopy \\ $\bigcup$ Vol. 37(2), March/April 2016}

TABLE II

Elements Taken Daily Through Nutrient, Air, Food, and Water (25)

\begin{tabular}{|c|c|c|c|c|c|}
\hline $\begin{array}{c}\text { Ele- } \\
\text { ments }\end{array}$ & $\begin{array}{c}\text { Food \& } \\
\text { Water } \\
\text { (mg/daily) }\end{array}$ & $\begin{array}{c}\text { Air } \\
\text { (mg/daily) }\end{array}$ & $\begin{array}{c}\text { Toxic } \\
\text { Effects } \\
\text { (mg/daily) }\end{array}$ & $\begin{array}{l}\text { Levels } \\
\text { in Body } \\
\text { (mg/daily) }\end{array}$ & $\begin{array}{l}\text { Half- } \\
\text { life } \\
(\mathrm{mg})\end{array}$ \\
\hline $\mathrm{Sb}$ & 1.000 & 0.0017 & 100 & 7.9 & 38 \\
\hline $\mathrm{Cu}$ & 1.325 & 0.0014 & $250-500$ & 72.0 & 80 \\
\hline $\mathrm{Ba}$ & 0.735 & 0.030 & 200 & 22 & 65 \\
\hline $\mathrm{Be}$ & 0.012 & 0.00004 & - & 0.03 & 180 \\
\hline $\mathrm{Bi}$ & 0.020 & 0.00076 & - & 0.23 & 5 \\
\hline $\mathrm{Hg}$ & 0.025 & - & - & - & 70 \\
\hline $\mathrm{Zn}$ & 14.500 & 0.0168 & - & 2300 & 933 \\
\hline $\mathrm{Fe}$ & 15.000 & 0.084 & - & 4200 & 800 \\
\hline Ag & 0.600 & - & 60 & 1 & 5 \\
\hline As & 0,002 & - & 2 & - & - \\
\hline $\mathrm{Cd}$ & 0.160 & 0.0074 & 3 & 50 & 200 \\
\hline $\mathrm{Sn}$ & 7.300 & 0.0006 & 2000 & 17 & 35 \\
\hline $\mathrm{Co}$ & 0.390 & 0.00012 & 500 & 1.5 & 9.5 \\
\hline $\mathrm{Pb}$ & 0.300 & 0.046 & - & 12.0 & 1460 \\
\hline $\mathrm{Cr}$ & 0.245 & 0.0011 & 200 & 1.8 & 616 \\
\hline $\mathrm{Mn}$ & 4.400 & 0.0288 & - & 12 & 17 \\
\hline Mo & 0.335 & 0.006 & - & 9.3 & 5 \\
\hline $\mathrm{Ni}$ & 0.600 & 0.00236 & - & 10 & 667 \\
\hline $\mathrm{Ti}$ & 1.375 & 0.0014 & - & 9 & 320 \\
\hline $\mathrm{U}$ & 0.050 & - & - & 0.7 & 100 \\
\hline V & 0.116 & 0.00916 & - & 22 & 42 \\
\hline $\mathrm{Zr}$ & 0.490 & - & - & 420 & 450 \\
\hline
\end{tabular}

ples were stored in sterile polyethylene containers $(1.0 \mathrm{~L})$ previously washed with $\mathrm{HNO}_{3}$, followed by rinsing with ultrapure water. At the collection points, the samples were acidified by adding concentrated $\mathrm{HNO}_{3}(1.5 \mathrm{~mL} / \mathrm{L})$ to reach a $\mathrm{pH}$ of 2.0, and were then brought to the laboratory (33). These samples were placed into the refrigerator until analysis. The time from sampling to measurement varied from 2 to 5 days. All of the samples were analyzed at the same time and under the same instrumental conditions.
TABLE III

ICP-OES Instrumental Operating Conditions

\begin{tabular}{|c|c|c|}
\hline Parameters & ICP-OES & HG-ICP-OES \\
\hline RF Power & $1450 \mathrm{~W}$ & $1375 \mathrm{~W}$ \\
\hline Plasma Gas Flow Rate & $15 \mathrm{~L} / \mathrm{min}$ & $17 \mathrm{~L} / \mathrm{min}$ \\
\hline Auxiliary Gas Flow Rate & $0.2 \mathrm{~L} / \mathrm{min}$ & $0.2 \mathrm{~L} / \mathrm{min}$ \\
\hline Nebulizer Gas Flow Rate & $0.6 \mathrm{~L} / \mathrm{min}$ & $0.8 \mathrm{~L} / \mathrm{min}$ \\
\hline Sample Flow Rate & $1.5 \mathrm{~L} / \mathrm{min}$ & $1.0 \mathrm{~L} / \mathrm{min}$ \\
\hline Viewing Mode & Axial - Radial & Axial \\
\hline \multicolumn{2}{|c|}{ Source Equilibration Time $15 \mathrm{~s}$} & $20 \mathrm{~s}$ \\
\hline Read delay & $45 \mathrm{~s}$ & 60 \\
\hline Nebulizer & $\begin{array}{l}\text { Cross-Flow } \\
\text { GemTip }^{\mathrm{TM}} \\
\text { Nebulizer } \\
\text { (HF resistant) }\end{array}$ & $\begin{array}{l}\text { Continuous } \\
\text { Flow Hydride } \\
\text { Generation }\end{array}$ \\
\hline Read & Peak Area & Peak Area \\
\hline Replicates & 3 & 3 \\
\hline Background Correction & $\begin{array}{l}\text { 2-point (manual } \\
\text { point correction) }\end{array}$ & $\begin{array}{l}\text { 2-point (manual } \\
\text { point correction }\end{array}$ \\
\hline Spray Chamber & $\begin{array}{l}\text { Scott-type Spray } \\
\text { Chamber }\end{array}$ & $\begin{array}{l}\text { Scott-type Spray } \\
\text { Chamber }\end{array}$ \\
\hline Detector & $\mathrm{CCD}$ & $\mathrm{CCD}$ \\
\hline Purge Gas & Nitrogen & Nitrogen \\
\hline Shear Gas & Air & Air \\
\hline Gas & Argon & Argon \\
\hline Analytical Wavelengths & $\begin{array}{l}\text { Al } 396.153 \mathrm{~nm} \\
\text { Sn } 189.927 \mathrm{~nm} \\
\text { B } 249.771 \mathrm{~nm} \\
\text { Be } 313.107 \mathrm{~nm} \\
\text { Ca } 393.366 \mathrm{~nm} \text {, } \\
\text { Cd } 228.804 \mathrm{~nm} \\
\text { Co } 228.616 \mathrm{~nm} \\
\text { Cr } 267.716 \mathrm{~nm} \\
\text { Fe } 238.204 \mathrm{~nm} \\
\text { K } 766.490 \mathrm{~nm} \\
\text { Mg } 280.271 \mathrm{~nm} \\
M n 257.610 \mathrm{~nm} \\
\text { Mo } 202.031 \mathrm{~nm} \\
\text { Na } 589.592 \mathrm{~nm} \\
\text { Ni } 231.604 \mathrm{~nm} \\
\text { Pb } 220.353 \mathrm{~nm} \\
\text { Zn } 206.200 \mathrm{~nm}\end{array}$ & $\begin{array}{l}\mathrm{Hg} 194.168 \mathrm{~nm} \\
\text { Se } 190.026 \mathrm{~nm} \\
\text { As } 188.979 \mathrm{~nm}\end{array}$ \\
\hline
\end{tabular}


TABLE IV

Details of Sampling Points

\begin{tabular}{|c|c|c|c|c|c|c|c|}
\hline $\begin{array}{l}\text { Villages/ } \\
\text { Towns }\end{array}$ & $\begin{array}{l}\text { Popu- } \\
\text { lation }\end{array}$ & $\begin{array}{l}\text { Borehol } \\
\text { Depth } \\
\text { (m) }\end{array}$ & $\begin{array}{c}\text { Tank } \\
\text { Volume } \\
\text { (L) }\end{array}$ & $\begin{array}{l}\text { Villages/ } \\
\text { Towns }\end{array}$ & $\begin{array}{l}\text { Popu- } \\
\text { lation }\end{array}$ & $\begin{array}{l}\text { Borehol } \\
\text { Depth } \\
\text { (m) }\end{array}$ & $\begin{array}{l}\text { Tank } \\
\text { Volume } \\
\text { (L) }\end{array}$ \\
\hline Develi & 586 & 180 & 100 & Haciosman & 227 & 290 & 50 \\
\hline Kabahidir & 532 & 152 & 50 & Kozan & 761 & 106 & 75 \\
\hline Egertutmaz & 347 & 140 & 50 & Kurtkayasi & 93 & 400 & 50 \\
\hline Tasdirek & 595 & 140 & 50 & Nahırkiraci & 429 & 152 & 50 \\
\hline Körtepe & 880 & 148 & 50 & Sati & 941 & 180 & 50 \\
\hline Pinaroglu & 154 & 152 & 50 & Bagivar & 8832 & 352 & 700 \\
\hline Sarıdalli & 441 & 384 & 100 & Çarikli & 4457 & 400 & 50 \\
\hline Yukarımollaali & 194 & 180 & 75 & Alpu & 304 & 455 & 50 \\
\hline Beneklitas & 199 & 78 & 50 & Bahçelievler & 293 & 40 & 100 \\
\hline Gözegöl & 166 & 400 & 50 & Basil & 517 & 412 & 50 \\
\hline Alçak & 124 & 100 & 50 & Gevendere & 1042 & 54 & 75 \\
\hline Yolboyu & 2773 & 114 & 150 & Güvercinlik & 372 & 28 & 100 \\
\hline Büyükkadi & 544 & 258 & 75 & Sancar & 142 & 150 & 50 \\
\hline Doguçanakçi & 79 & 300 & 50 & Tanısik & 21 & 168 & 50 \\
\hline Erimli & 953 & 300 & 50 & Yukarınasirlar & ar 128 & 80 & 50 \\
\hline
\end{tabular}

\section{RESULTS AND DISSCUSSION}

\section{Standard Solutions, Reagents, and Calibration Curves}

The working standards were prepared by serial volume/volume dilution in polypropylene vials (Sarsted ${ }^{\circledR}$, Germany). Micropipettes (Eppendorf ${ }^{\circledR}$, Germany) with disposable tips were used for pipetting all solutions. The reagents and acids were of analytical grade and used without further purification.

All standard solutions were prepared by using ultrapure water. The standard solutions for the analysis were made up of concentrations for $\mathrm{Ca}, \mathrm{Na}$ and $\mathrm{Mg}$ at 50, 100,150 , and $200 \mathrm{mg} / \mathrm{L}$; and for $\mathrm{K}$, $\mathrm{Cr}, \mathrm{Mo}, \mathrm{Sn}, \mathrm{Cd}, \mathrm{Co}, \mathrm{Be}, \mathrm{Ni}, \mathrm{Pb}, \mathrm{Al}$, $\mathrm{B}, \mathrm{Fe}, \mathrm{Mn}$, and $\mathrm{Zn}$ at $0.05 \mathrm{mg} / \mathrm{L}$, $0.1 \mathrm{mg} / \mathrm{L}, 0.25 \mathrm{mg} / \mathrm{L}, 0.5 \mathrm{mg} / \mathrm{L}$, and $1.0 \mathrm{mg} / \mathrm{L}$. They were prepared with dilute distilled water from high-purity ICP multi-element stock solutions of $1000 \mathrm{mg} / \mathrm{L}$ (No. 1213901, High Purity Standards, Charleston, SC, USA).
The As, Se, and Hg concentrations were determined by using the hydride generation system of the ICP-OES. The Hg, As, and Se standard solutions $(5.0,10,20$, and 40 $\mu \mathrm{g} / \mathrm{L}$ ) were prepared in $5 \% \mathrm{HCl}$ $0.2 \%(\mathrm{w} / \mathrm{v}), \mathrm{NaBH}_{4}$ was used in the experiments. A $1.0-\mathrm{mL}$ mixture of ascorbic acid and KI (prepared by dissolving $5.0 \mathrm{~g}$ ascorbic acid and $5.0 \mathrm{~g}$ of $\mathrm{KI}$ in $100 \mathrm{~mL}$ ultrapure water) was added to the samples containing 5\% $\mathrm{HCl}$ for hydride generation of As. Then, 2 to 3 drops of $\mathrm{KMnO}_{4}(5 \% \mathrm{w} / \mathrm{v})$ were added to each of the samples for hydride generation of $\mathrm{Hg}$. The standards and samples diluted with $\mathrm{HCl}(1: 1$, $\mathrm{v} / \mathrm{v})$ were placed into hot water $\left(90{ }^{\circ} \mathrm{C}\right)$ for 20 minutes. After cooling to room temperature, they were subjected to the hydride generation procedure for Se. Ultrapure water, acidified with Suprapur ${ }^{\circledR}$ nitric acid (E-Merck, Germany) was used as the calibration blank and for all dilutions. The standard calibration curves were found to be linear with a correlation coefficient of 0.999 . The concentration of each element was calculated using calibration curves. Some of the trace elements in the samples, which were outside the standard calibration, were analyzed by dilution with ultrapure water.

The limit of detection (LOD) and the limit of quantification (LOQ) for each metal were determined as follows: the analytical curves were performed for 10 independent analyses of a blank solution spiked with the metal at a level of lower concentration. The LOD and LOQ were calculated from the standard deviation $(\alpha)$ of the determinations $(\mathrm{LOD}=3 \alpha$ and $\mathrm{LOQ}=$ $10 \alpha$ ), and the analytical results are listed in Table V $(17,18)$.

High purity certified reference material (CRM) of TMDW-B Drinking Water (High Purity Standards, Charleston, SC, USA) was used to determine the precision and accuracy of the method. The CRM sample was diluted with ultrapure water and acidified with nitric acid according to the range of the standard solution. The CRM sample was analyzed in triplicate by ICP-OES, and the results listed in Table $\mathrm{V}$ were in good agreement with the certified values.

The increase in population in the Diyarbakır province means that the available terrestrial water is not sufficient and resulted in also using borehole water. These waters are used for both drinking and irrigation purposes. Thus, the importance of constant analysis of these waters is paramount. Table IV lists the borehole water depths and the number of people of each area benefiting from these waters. The trace elements $\mathrm{Al}, \mathrm{As}, \mathrm{B}, \mathrm{Be}, \mathrm{Ca}$, $\mathrm{Cd}, \mathrm{Co}, \mathrm{Cr}, \mathrm{Fe}, \mathrm{Hg}, \mathrm{K}, \mathrm{Mg}, \mathrm{Mn}, \mathrm{Mo}$, $\mathrm{Na}, \mathrm{Ni}, \mathrm{Pb}, \mathrm{Se}, \mathrm{Sn}$, and $\mathrm{Zn}$ were detrmined by using ICP-OES analysis. For this study, the LOD and LOQ values were determined for each element, and the values were found to be within tolerable limits (Table V). A certified reference 
TABLE V

Analytical Characteristics of the ICP-OES for the Determination of Al, As, B, Be, Ca, Cd, Co, Cr, Fe, Hg, K, Mg, Mn, Mo, Na, Ni, Pb, Se, Sn, and $\mathrm{Zn}$ in CRM TMDW-B Drinking Water Sample

\begin{tabular}{lrrrrr}
\hline Elements & $\begin{array}{c}\mathrm{LOD} \\
(\mu \mathrm{g} / \mathrm{L})\end{array}$ & $\begin{array}{r}\mathrm{LOQ} \\
(\mu \mathrm{g} / \mathrm{L})\end{array}$ & $\begin{array}{c}\text { Certified } \\
(\mu \mathrm{g} / \mathrm{L})\end{array}$ & $\begin{array}{c}\text { Found } \\
(\mu \mathrm{g} / \mathrm{L})\end{array}$ & $\begin{array}{c}\text { Recovery } \\
(\%)\end{array}$ \\
\hline $\mathrm{Al}$ & 5.7 & 18.9 & 125 & $121.3 \pm 10.2$ & 97 \\
$\mathrm{As}^{\mathrm{a}}$ & 0.022 & 0.073 & 10 & $10.1 \pm 0.8$ & 101 \\
$\mathrm{~B}$ & 11.2 & 37.3 & 150 & $145 \pm 7.5$ & 97 \\
$\mathrm{Be}$ & 1.2 & 4.0 & 15 & $14.8 \pm 0.9$ & 99 \\
$\mathrm{Ca}$ & 1.2 & 4.1 & 31000 & $30180 \pm 380$ & 97 \\
$\mathrm{Cd}$ & 0.035 & 0.116 & 10 & $9.8 \pm 0.5$ & 98 \\
$\mathrm{Co}$ & 2.1 & 7.0 & 25 & $24.1 \pm 0.9$ & 96 \\
$\mathrm{Cr}$ & 0.05 & 0.17 & 20 & $19 \pm 0.8$ & 95 \\
$\mathrm{Fe}$ & 0.75 & 2.45 & 90 & $89 \pm 1.5$ & 99 \\
$\mathrm{Hg} 1$ & 1.0 & 3.33 & - & & - \\
$\mathrm{K}$ & 1.9 & 6.33 & 2500 & $2456 \pm 41$ & 98 \\
$\mathrm{Mg}$ & 0.9 & 3.0 & 8000 & $7913 \pm 75$ & 99 \\
$\mathrm{Mn}$ & 3.2 & 10.7 & 40 & $38.2 \pm 1.1$ & 96 \\
$\mathrm{Mo}$ & 4.1 & 13.7 & 110 & $102 \pm 5.6$ & 93 \\
$\mathrm{Na}$ & 5.4 & 8.0 & 22000 & $21012 \pm 312$ & 96 \\
$\mathrm{Ni}$ & 3.4 & 11.3 & 60 & $56.2 \pm 1.3$ & 94 \\
$\mathrm{~Pb}$ & 0.095 & 0.32 & 20 & $19.2 \pm 0.6$ & 96 \\
$\mathrm{Se} 1$ & 2.1 & 7.00 & 11 & $10.8 \pm 0.7$ & 98 \\
$\mathrm{Sn}$ & - & - & - & & - \\
$\mathrm{Zn}$ & 0.048 & 0.16 & 75 & $76 \pm 1.5$ & 101 \\
\hline
\end{tabular}

${ }^{\text {a }}$ Measured by HG-ICP-OES.

material was used to verify the accuracy of the method, and the results were in good agreement (Table V). The standard calibration curves were found to be linear with a correlation coefficient of 0.999 ; the concentration of each element was calculated using calibration curves. The concentrations of $\mathrm{Na}$, $\mathrm{K}, \mathrm{Ca}, \mathrm{Se}, \mathrm{Fe}, \mathrm{Mg}$ and $\mathrm{Zn}$ in the 30 samples were determined by ICPOES at the respective wavelengths, and the results are shown in the Table VI. The concentrations of $\mathrm{Al}$, As, B, Be, Cd, Co, Cr, Hg, Mn, Mo, $\mathrm{Ni}, \mathrm{Pb}$, and $\mathrm{Sn}$ in the samples were found lower than the LOD.

This study showed that the elements $\mathrm{Al}, \mathrm{As}, \mathrm{B}, \mathrm{Be}, \mathrm{Ca}, \mathrm{Cd}, \mathrm{Co}, \mathrm{Cr}$, $\mathrm{Fe}, \mathrm{Hg}, \mathrm{K}, \mathrm{Mg}, \mathrm{Mn}, \mathrm{Mo}, \mathrm{Na}, \mathrm{Ni}, \mathrm{Pb}$, $\mathrm{Sn}$, and $\mathrm{Zn}$ as determined in the 30 borehole water samples were within the allowable limits. How- ever, the Se concentration in all six samples was high (0.11-0.12 $\mu \mathrm{g} / \mathrm{L})$, while the MAC limit is $>0.01 \mathrm{mg} / \mathrm{L}$. The results of the analysis, as shown in the Table VII, were compared with the regulated limits from Turkey (TS-266), WHO, and the EU. Several studies have revealed that Se is important to health, but a very low Se status $(<10 \mu \mathrm{g})$ in humans has been associated with juvenile, multifocalmyocarditis (Keshan disease), and chondrodystrophy (Kaschin-Beck disease). A high dietary intake of Se $(>1000 \mu \mathrm{g})$, as shown in high urinary Se levels, manifests itself in gastrointestinal disturbances, discoloration of the skin, and tooth decay $(34,35)$. Table VII lists the WHO recommended dietary allowance of Se for male and female according to age as determined.
In a study of well waters in the Urfa province (SE Anatolia), the Se levels were found to be higher than the recommended legal regulations ( $>0,01 \mathrm{mg} / \mathrm{L})(36)$. The Urfa province is neighboring Diyarbakır and is close to the Euphrates. In this study, Se was found to be high in borehole water samples. In areas close to the river, trace metal concentrations are high, but they decrease closer to the mountainous regions. For instance, the region around the Karacadag Mountain is covered with porous, hard, black volcanic rocks, which may prevent the leakage of elements to the borehole waters. The high amount of Se in areas close to the Tigris River might likely be contaminated from soil, sandy soil, or agricultural waste.

The analytical results show that the borehole waters in Diyarbakır contain major and toxic trace elements ( $\mathrm{Al}, \mathrm{As}, \mathrm{B}, \mathrm{Be}, \mathrm{Ca}, \mathrm{Cd}, \mathrm{Co}, \mathrm{Cr}$, $\mathrm{Fe}, \mathrm{Hg}, \mathrm{K}, \mathrm{Mg}, \mathrm{Mn}, \mathrm{Mo}, \mathrm{Na}, \mathrm{Ni}, \mathrm{Pb}$, $\mathrm{Se}, \mathrm{Sn}$, and $\mathrm{Zn}$ ), but they are present at very low levels, which makes the borehole waters tested an unpolluted and safe source. Thus, all of these trace elements, except Se, were within tolerable limits. Table VII lists the recommended daily allowance for Se, which shows that the borehole water samples in the areas of Sat, Doguçanakçi, Kozan, Haciosman, Çarıkli, and Güvercinlik have higher than allowed values and thus can be a health hazard. However, in all samples, the concentrations of $\mathrm{Al}, \mathrm{B}, \mathrm{Co}, \mathrm{Mn}, \mathrm{Pb}, \mathrm{Sn}, \mathrm{As}, \mathrm{Be}, \mathrm{Cd}$, $\mathrm{Cr}, \mathrm{Hg}, \mathrm{Mo}$, and $\mathrm{Ni}$ were found to be lower than the LOD.

\section{CONCLUSION}

The results of this study demonstrate that the ICP-OES method can be considered useful for the routine determination of trace elements in waters and similar matrices, as well as for quality control purposes. The accuracy of the method was verified and compared well with the 
TABLE VI

$\mathrm{Na}, \mathrm{K}, \mathrm{Ca}, \mathrm{Se}, \mathrm{Fe}, \mathrm{Mg}$, and $\mathrm{Zn}$ Determination in Borehole Waters by ICP-OES $^{\text {a }}$ (Se concentrations were measured by HG-ICP-OES)

\begin{tabular}{lccccccc}
\hline Sample & $\begin{array}{c}\mathrm{Na} \\
\text { Points }\end{array}$ & $\begin{array}{c}\mathrm{K} \\
(\mathrm{mg} / \mathrm{L})\end{array}$ & $\begin{array}{c}\mathrm{Ca} / \mathrm{L}) \\
(\mathrm{mg} / \mathrm{L})\end{array}$ & $\begin{array}{c}\mathrm{Se} \\
(\mathrm{mg} / \mathrm{L})\end{array}$ & $\begin{array}{c}\mathrm{Fe} \\
(\mathrm{mg} / \mathrm{L})\end{array}$ & $\begin{array}{c}\mathrm{Mg} \\
(\mathrm{mg} / \mathrm{L})\end{array}$ & $\begin{array}{c}\mathrm{Zn} \\
(\mathrm{mg} / \mathrm{L})\end{array}$ \\
\hline Sati & 35.30 & 1.65 & 54.48 & 0.11 & $\mathrm{ND}$ & 20.18 & $\mathrm{ND}$ \\
Doguçanakçi & 12.71 & 0.90 & 60.22 & 0.12 & $\mathrm{ND}$ & 15.32 & 0.16 \\
Kozan & 39.38 & 1.77 & 46.71 & 0.12 & $\mathrm{ND}$ & 23.73 & $\mathrm{ND}$ \\
Haciosman & 46.30 & 0.97 & 40.22 & 0.11 & $\mathrm{ND}$ & 20.08 & $\mathrm{ND}$ \\
Bagivar & 46.28 & 2.30 & 50.44 & 0.10 & $\mathrm{ND}$ & 25.28 & 0.12 \\
Yk.Mollaali & 18.01 & 1.40 & 31.98 & 0.07 & $\mathrm{ND}$ & 17.32 & $\mathrm{ND}$ \\
Çarıkli & 30.79 & 2.02 & 59.46 & 0.11 & 0.09 & 28.62 & 0.52 \\
Kurtkayasi & 20.33 & 1.99 & 40.79 & 0.09 & $\mathrm{ND}$ & 23.92 & $\mathrm{ND}$ \\
Kabahidir & 20.97 & 0.76 & 41.60 & 0.08 & $\mathrm{ND}$ & 15.76 & $\mathrm{ND}$ \\
Egertutmaz & 39.95 & 1.07 & 50.68 & 0.08 & $\mathrm{ND}$ & 18.66 & $\mathrm{ND}$ \\
Tanısik & 24.66 & 2.61 & 103.2 & 0.10 & 0.10 & 38.70 & $\mathrm{ND}$ \\
Bahçelievler & 22.38 & 1.11 & 42.79 & 0.09 & $\mathrm{ND}$ & 21.32 & 0.08 \\
Sancar & 19.64 & 1.05 & 57.71 & 0.08 & $\mathrm{ND}$ & 22.80 & $\mathrm{ND}$ \\
Basil & 21.28 & 2.35 & 115.5 & 0.09 & $\mathrm{ND}$ & 41.85 & $\mathrm{ND}$ \\
Gevendere & 21.65 & 2.51 & 60.90 & 0.08 & $\mathrm{ND}$ & 33.12 & $\mathrm{ND}$ \\
Güvercinlik & 17.74 & 2.16 & 95.88 & 0.12 & $\mathrm{ND}$ & 33.82 & 0.06 \\
Yk.Nasirlar & 19.34 & 1.35 & 53.93 & 0.07 & $\mathrm{ND}$ & 23.14 & $\mathrm{ND}$ \\
Alpu & 34.84 & 0.94 & 37.26 & 0.07 & $\mathrm{ND}$ & 13.11 & $\mathrm{ND}$ \\
Körtepe & 18.25 & 4.62 & 71.06 & 0.08 & $\mathrm{ND}$ & 23.80 & $\mathrm{ND}$ \\
Tasdirek & 16.14 & 0.79 & 55.48 & 0.08 & $\mathrm{ND}$ & 19.09 & $\mathrm{ND}$ \\
Yolboyu & 18.84 & 3.07 & 14.37 & $\mathrm{ND}$ & $\mathrm{ND}$ & 12.79 & $\mathrm{ND}$ \\
Beneklitas & 35.01 & 2.99 & 57.33 & $\mathrm{ND}$ & $\mathrm{ND}$ & 38.55 & $\mathrm{ND}$ \\
Sarıdalli & 87.24 & 3.02 & 34.62 & 0.07 & $\mathrm{ND}$ & 16.87 & 0.15 \\
Büyükkadi & 73.21 & 1.23 & 28.54 & $\mathrm{ND}$ & $\mathrm{ND}$ & 6.996 & 0.17 \\
Develi & 66.02 & 1.72 & 9.623 & $\mathrm{ND}$ & 0.21 & 5.207 & $\mathrm{ND}$ \\
Alçak & 19.13 & 1.61 & 36.62 & 0.08 & $\mathrm{ND}$ & 26.43 & $\mathrm{ND}$ \\
Erimli & 72.09 & 1.31 & 52.65 & 0.07 & 0.10 & 10.52 & 0.42 \\
Gözegöl & 22.84 & 2.69 & 59.23 & 0.09 & $\mathrm{ND}$ & 27.88 & $\mathrm{ND}$ \\
Pinaroglu & 53.45 & 1.54 & 19.93 & 0.07 & 0.20 & 12.11 & $\mathrm{ND}$ \\
Nahirkıraci & 111.4 & 0.92 & 11.17 & $\mathrm{ND}$ & $\mathrm{ND}$ & 2.69 & $\mathrm{ND}$ \\
\hline & & & & & & & \\
\hline & & & &
\end{tabular}

${ }^{a}$ The $\mathrm{Al}, \mathrm{As}, \mathrm{B}, \mathrm{Be}, \mathrm{Cd}, \mathrm{Co}, \mathrm{Cr}, \mathrm{Hg}, \mathrm{Mn}, \mathrm{Mo}, \mathrm{Ni}, \mathrm{Pb}$ and $\mathrm{Sn}$ concentrations were lower than the LOD and were not listed in this table.

b ND: Not detected.

certified values. Analysis of the borehole waters revealed that six of the samples had higher Se levels than allowed by legal regulations. The concentrations of $\mathrm{Na}, \mathrm{K}, \mathrm{Ca}$, Se, $\mathrm{Fe}, \mathrm{Mg}$, and $\mathrm{Zn}$ in the 30 samples were found to be lower than the maximum allowed values. The elements $\mathrm{Al}, \mathrm{As}, \mathrm{B}, \mathrm{Be}, \mathrm{Cd}, \mathrm{Co}, \mathrm{Cr}, \mathrm{Hg}$, $\mathrm{Mn}, \mathrm{Mo}, \mathrm{Ni}, \mathrm{Pb}$ and $\mathrm{Sn}$ were found to be lower than the LOD. How- ever, the Se concentrations in six samples were higher than the MAC limit of $>0.01 \mathrm{mg} / \mathrm{L}$. Recovery values were achieved in the 93-101\% range for the CRM TMDW-B Drinking Water Sample. The concentration ranges of $\mathrm{Na}, \mathrm{K}, \mathrm{Ca}, \mathrm{Mg}, \mathrm{Se}$, $\mathrm{Fe}, \mathrm{Zn}$ were $12.71-111.4 \mathrm{mg} / \mathrm{L}$, $0.76-3.07 \mathrm{mg} / \mathrm{L}, 9.62-115.5 \mathrm{mg} / \mathrm{L}$, $2.69-41.85 \mathrm{mg} / \mathrm{L},<\mathrm{LOD} 0.12 \mathrm{mg} / \mathrm{L}$, $<$ LOD $0.21 \mathrm{mg} / \mathrm{L}$, and <LOD 0.52 $\mathrm{mg} / \mathrm{L}$, respectively. The results obtained in this study were in good agreement with the legal limits for other elements such as $\mathrm{Sb}, \mathrm{Cu}, \mathrm{Ba}$, $\mathrm{Bi}, \mathrm{Ag}, \mathrm{Sn}, \mathrm{Ti}, \mathrm{U}, \mathrm{V}$, and $\mathrm{Zr}$.

Received June 25, 2015.

\section{REFERENCES}

1. K.C. Chun, R.W. Chang, G.P. Williams,Y.S. Chang, D. Tomasko, K. LaGory, J.Ditmars, H.D. Chun and B.K. Lee, Environ. Eng. Policy 2, 131 (2001)

2. A.V.M. Wong and M.H. Wong, Reg. Environ. Change 4, 28 (2003).

3. N.A. Nkonoa, A.O. Ogunsuab, A.F. Oluwole, N.I. Wardd, O.A. Akanleeand and N.M. Spyrou, Sci. Total Environ. 208, 1, (1997).

4. C. Qu, Z. Ma, J. Yang, Y. Lie, J. Bi and L. Huang, Apple Academic Press, Oakville, Ontario, Canada, 129 (2014).

5. O. Akba, E. Kilinc, I. Aydin, S. Erdogan, F. Aydin, M. Z. Duz and C. Hamamci, At. Spectrosc. 34, 48 (2013).

6. D. M. Polyakova and N. V. Zarubinab, Water Resource 41, 666 (2014).

7. E. N.Chernova, L. A. Lobas, M. Yu. Kovalev and E.V. Lysenko, Water Resource 41, 319 (2014).

8. WHO, Selenium in drinking-water background document for development of guidelines for drinkingwater quality, Geneva, Switzerland, (2011).

9. WHO, Water Quality and Health Strategy, Geneva, Switzerland (2013).

10. J.M. Pearce, Eur. Neurol. 57, 118 (2007).

11. E. Kilinc, F. Aydin and M. Z. Duz, At. Spectrosc. 33, 173 (2012).

12. V.A. Lemos, R.S. Franca and B.O. Moreira, Purif. Technol. 54, 349 (2007).

13. J.R. Chen and K.C. Teo, Anal. Chim. Acta.434, 325 (2001).

14. L. A. Escudero, L. D. Martinez, J. A. Salonia and J. A.Gasquez, Microchem. J. 95, 164 (2010). 


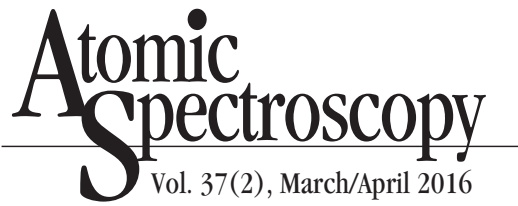

TABLE VII

Recommended Dietary Allowances for Se $(34,35)$

\begin{tabular}{lcccc}
\hline Age & $\begin{array}{c}\text { Male } \\
(\mu \mathrm{g})\end{array}$ & $\begin{array}{c}\text { Female } \\
(\mu \mathrm{g})\end{array}$ & $\begin{array}{c}\text { Pregnancy } \\
(\mu \mathrm{g})\end{array}$ & $\begin{array}{c}\text { Lactation } \\
(\mu \mathrm{g})\end{array}$ \\
\hline Birth to 6 months & 15 & 15 & - & - \\
7-12 months & 20 & 20 & - & - \\
1-3 years & 20 & 20 & - & - \\
4-8 years & 30 & 30 & - & - \\
9-13 years & 40 & 40 & - & - \\
14-18 years & 55 & 55 & 60 & 70 \\
$19-50$ years & 55 & 55 & 60 & 70 \\
$51+$ years & 55 & 55 & - & - \\
\hline
\end{tabular}

15. D. Mohan, U. Charles and J. Pittman, J. Hazard. Mater. 142, 1 (2007).

16. G. Huaming, S. Doris and B. Zsolt, J. Colloid. Interf. Sci. 315, 47 (2007).

17. K. S. Celik, F. Aydin, M.Z. Duz, I. Aydin, S. Erdogan, O. Akba and C. Hamamci, At. Spectrosc. 35, 200 (2014).

18. M. Z. Duz, K. S. Celik, I. Aydin, S. Erdogan, F. Aydin and C. Hamamci, At. Spectrosc. 33, 78 (2012).

19. L. K.Wang, J.P. Chen, Y. Hung and N. K. Shammas, CRC Press, Boca Raton, FL, USA, 475 (2009).

20. H. Sereshti, Y. E. Heravi and S.Samadi, Talanta 97, 235 (2012).

21. X. Zhu, X. Chang, Y. Cui, X. Zou, D. Yang and Z. Hu, Microchem.J. 86, 189 (2007).

22. N. Philiswa, J. Nomngongo, N. Catherine, A.M.Titus and B. M. Msagati, Phys. Chem. Earth 66, 83 (2013),

23. M.H. Karbasia, B. Jahanparas, M. Shamsipurb and J. Hassan, J. Hazard. Mater.170,151 (2009).

24. WHO, Guidelines for DrinkingWater Quality, Fourth Edition(2011).

25. WHO, The contribution of drinkingwater to total dietary intakes of selected trace mineral nutrients in the United States, Geneva, Switzerland Draft, August (2004).

26. As per Canadian or B.C. Health Act Safe Drinking Water Regulation, Task Force of Canadian Council of Resource \& Envir. Ministers Guidelines for Canadian Drinking Water,
BC, Canada, Reg 230/92\& 390 Sch. 120 (2001).

27. Turkish Standard Waters for Human Consumption, TS266, Ankara, Turkey (2005).

28. M. Varol, B. Gokotand, and A. Bekleyen, Water Pract. Tech. 5, 1 (2010).

29. M. Kankaland and E. Uzlu, Water Resources 41, 649 (2014).

30. Standard Methods for the Examination of Water and Wastewater, 19th edition, Part No. 1060, 3000), Metals $300(3114,3120)$, ISBN 0-87553223-3, Stock No. 065 (1996).

31. U.S. EPA Method, Determination of Metals and Trace Elements in Water and Wastes by ICP-OES, Cincinnati, Ohio, U.S. (2007).

32. Environment state report of the district of Diyarbakır, Environment and Forest Institution of Turkish State Diyarbakır Governorship, Anonymous (2007).

33. O. Akba, A. Baysal, C. Hamamci, M. Merdivan and B. Gumgum, Fresen. Environ. Bull.12, 1412 (2003).

34. Selenium in drinking water background document for development of WHO. Guidelines for drinkingwater quality. Publications of the WHO (2011).

35. B. Pezzarossa, F. Goriniand G. Petruzelli, Heavy metal and selenium distribution and bioavailability in contaminated sites, CRC Press, Boca Raton, FL, USA, 93 (2011).

36. F. Temamogullari and A. H. Dinçoglu, Kafkaf Univ. Vet. Fak. Derg. 16, 199 (2010). 